\title{
Effect of Financial Structure Ratios on Profitability: Panel Data Analysis on Manufacturing Sector
}

\author{
Hakan ÖZÇELIK iDa Zühal ARSLAN iD b \\ a Süleyman Demirel University, Faculty of Econonics and Administrative Sciences, Isparta Turkey, hakanozcelik@sdu.edu.tr \\ b Isparta Applied Sciences University, Yalvaç Büyükkutlu Academy of Applied Sciences, Isparta, Turkey.zuhalkucukcakal@sdu.edu.tr
}

\begin{tabular}{|c|c|}
\hline ARTICLE INFO & ABSTRACT \\
\hline $\begin{array}{l}\text { Keywords: } \\
\text { Financial Structure } \\
\text { Panel Data Analysis } \\
\text { Manufacturing Sector } \\
\text { Financial Leverage }\end{array}$ & $\begin{array}{l}\text { Purpose - By increasing their profitability, businesses can achieve their goals such as economic } \\
\text { growth, regularity and increasing their market value. Financial structure is one of the main } \\
\text { factor that affecting profitability. The resource components used in the financing of assets, } \\
\text { directly affect the sustainability of profitability. In profit planning, businesses need to take into } \\
\text { account the resource components that they will use in asset financing. The development of } \\
\text { studies on the impact of the equity and liability components that compose the financial structure } \\
\text { on the profitability will contribute to the field of business administration. In this context, the aim } \\
\text { of this study is to investigate the effect of financial structure on profitability. }\end{array}$ \\
\hline $\begin{array}{l}\text { Revised } 20 \text { March } 2019 \\
\text { Accepted } 22 \text { March } 2019\end{array}$ & $\begin{array}{l}\text { Design/methodology/approach - Within this scope, to measure the effect of financial structure } \\
\text { rates on profitability, the regression model was tested by panel data analysis which developed } \\
\text { as a result of the literature review. The tests were carried out in the Eviews } 9 \text { package program. } \\
\text { The data obtained from the financial statements of } 155 \text { publicly-traded company in the İstanbul } \\
\text { stock exchange ( BIST) Manufacturing Industry between 2008-2017 were used in the study. }\end{array}$ \\
\hline Research Article & $\begin{array}{l}\text { Findings - As a result of the analyzes, it was determined that the borrowing ratios affected the } \\
\text { asset profitability as financial structure ratios, and this effect was positive in the long-term } \\
\text { borrowing ratio and negative in the short-term borrowing ratio. } \\
\text { Discussion - Findings obtained from the study; has great importance for investors, researchers } \\
\text { and the top management of enterprises. }\end{array}$ \\
\hline
\end{tabular}

\section{Introduction}

Today, companies are in need of capital in line with their growth targets and benefit from two financial sources: liability and equity. While liability refers to the the obligations of the company that require reimbursement for creditors in certain periods of time, equity is the remaining portion of the company's assets after meeting the obligations of the company to creditors (Ross et al., 2008: 23; Berk et al., 2012: 26). Capital structure decision is one of the vital significant topic for enterprises as it determine their financial risks and survival (Arslan and Boz, 2017:213). Considering that the main objective of the firms is the maximization of the market value, it is important to know the capital sources of firms from where and to what extend. In this context, the status of capital structure is continuously examined and discussed in the field of financial management. These discussions focus on whether the capital structure has an impact on the cost of capital and the market value of the firm and also, it has been carried out frequently about what are these determinants of the capital structure endemic to the firm (Sheikh and Wang, 2011: 118).

The financial structure of a firm consists of short and long-term liabilities and equity, and explains the resources of assets from where they are financed. In case of use of liabilities, the firm is confronted with the obligation to pay a certain amount of interest as the usage cost of these resources. However, in return, it can increase profitability by using liabilities. Therefore, financial leverage effect is mentioned in firms which use liabilities (Sarraslan \& Erol, 2014: 194). Financial leverage refers to the change in the net income of the company due to the existence of fixed resource costs within the company's liability structure. Therefore, in order to be able to speak about financial leverage, the existence of a fixed cost fund is necessary (Besley and Brigham, 2000: 159). Financial ratios are used as an indicator of the capacity of enterprises to benefit from borrowing in asset financing and these ratios are expressed by financial structure or leverage ratios. By using 
these ratios, it is informed about the positive or negative effect of borrowing on the profitability of enterprises and the liability and equity components used in the financing of assets (Bektöre et al., 2015: 159).

Financial leverage ratios indicate the extent to which the firm is financed by liability. The firm's use of liability capital has both positive and negative aspects. As the company borrows, since the financial leverage rises, it will be difficult to meet its obligations related to its debts, and perhaps it may be bankrupt and this will cause a disruptive process for those who associated with the company. For this reason, the firm's liabilities increase the financial risk of the firm, which means that the firm's capital cost increases. On the other hand, liabilities are an important source of financing. Since the interest is deducted from tax assessment, it provides tax advantage. Liability capital is a financial resource that is easy to obtain, lower than the equity capital and does not hinder the rights of shareholders. If it is used in a balanced way and its economic timing is considered, it increases the profits of the company and therefore the profits per share. Theoretically, the firm can borrow until the rate of interest = company profit ratio. As seen in Table 1, significant leverage ratios are: Total liabilities / Total Assets, Total liability / Equity, Short Term Liabilities / Total Liabilities, Short Term Liabilities / Total Assets, Equity Multiplier (Okka, 2009: 109-110).

Table 1. Rates of Financial Structure (Financial Leverage Ratios)

\begin{tabular}{|l|l|}
\hline $\begin{array}{l}\text { 1. Liability Ratio: Indicates the rate of barrowing at which } \\
\text { the assets are financed.The most commonly used rate.Total } \\
\text { liabilities include all short-term and long-term liabilities.As } \\
\text { the firm's liability ratio increases, its financial risk is } \\
\text { assumed to increase. It is recommended that this ratio } \\
\text { should not be higher than the sector average. }\end{array}$ & $\begin{array}{l}\text { Liability Rate = Total Liabilities / Total } \\
\text { Assets }\end{array}$ \\
\hline $\begin{array}{l}\text { 2. Liabilities / Equity ratio: This is an examination of the } \\
\text { Liability ratio from another perspective. Indicates to what } \\
\text { extent the partners and creditors contribute capital to the } \\
\text { firm. This ratio is also called the firm's financial leverage. }\end{array}$ & $\begin{array}{l}\text { Liability / Equity Capital Ratio = Total } \\
\text { Liabily / Equity Capital }\end{array}$ \\
\hline $\begin{array}{l}\text { 3. The weight ratio of short-term Liability: It shows the } \\
\text { status of the short-term liabilities of the firm and the weight } \\
\text { of the firm in the financial structure. Height of the rate; } \\
\text { states that the payables of the firm are close to their } \\
\text { maturities, that the payment risk is high and that they } \\
\text { should establish financial policies for payment. }\end{array}$ & $\begin{array}{l}\text { Liability / Total Liabilities } \\
\text { Short Term Debt Ratio = Short Term } \\
\text { Liabilities / Long Term Liabilities } \\
\text { Short Term Debt Assets Coverage Ratio = } \\
\text { Current Liabilities / Total Assets }\end{array}$ \\
\hline $\begin{array}{l}\text { 4. Equity capital multiplier ratio: Indicates how many } \\
\text { times that the total assets are of the own capital. } \\
\text { Equity = Total Asset - Liabilities. It is in favor of the firm if } \\
\text { this ratio is low, indicating that the company is under a low } \\
\text { debt burden. }\end{array}$ & $\begin{array}{l}\text { Equity Capital multiplier = Total Assets / } \\
\text { Equity capital. }\end{array}$ \\
\hline
\end{tabular}

Source: (Okka, 2009: 109-110).

It is stated that the increase in the amount of Liability within the financial structure is not suitable for the value of the company (Mathur and Singh, 2011, 256). Profitability plays a critical role in the financial structure of enterprises, as it directly affects internal resources, which is one of the three major sources of finance (Chen and Zhau, 2005: 1). The profitability relationship of the financial structure may vary from country to country, from sector to sector and from company to company. In addition to contributing to economic growth and increasing welfare, manufacturing industry is a key sector in productivity growth, innovation and exports in developed countries (McKinsey, 2012: 17). At this point in the manufacturing sector, that is in a strategic position for Turkey's economy, the impact on profitability of the financial structure ratios are becoming important.

In the literature, the effect of financial structure ratios of profitability remains limited in addressing work for Turkey's economy, and work on a sectoral basis seems to be few. It is thought that this study will contribute 
to the literature. The study consists of four parts. After this introductory chapter, in the second part, the international structure of the financial structure is given. In the third chapter, the data to be used in the research, the research model, method and findings are included and the results and recommendations section is mentioned in the fourth section. It is foreseen that working updated data and that financial executives will have a driving effect in their decisions.

\section{Literature}

The combination of the capital resources used by the companies in financing their investments and activities, and the variables affecting this composition, and many different studies in developed and developing countries were carried out. In this section, firstly the studies on the effect of capital structure decisions on profitability are examined and related studies and results are summarized in the literature.

It is believed all the ideas such as; the capital structure of enterprises, obtaining a tax advantage by borrowing, financing the capital structure with liabilities instead of the use of own funds since it is more advantageous and the use of liabilities reduces the cost of capital after taxes are laid by Modigliani and Miller's theories (1993). The theories of Modigliani and Miller ( from 1963 to the present ) about Capital structure theory, balancing, financial hierarchy, representation costs were used to explain the sign effect (Topaloglu, 2018: 64).

In the studies conducted on the determinants of the capital structure, the dependent variable was determined as financial leverage ratio. On the other hand, as an independent variable, the company's profitability ratios, firm size, firm age, growth opportunities, yield on common stock, non-debt tax shield, asset structure, ownership structure, size of board of directors, interest rates, tax rates, liquidity ratios, inflation rate, business risk, borrowing status, etc. variables were determined. Regarding the capital structure, there are different opinions on the relationship between leverage and profitability. In many studies in the literature, a negative relationship between leverage and profitability based on the theory of finance hierarchy has been reached.

Cortez and Susanto (2012), in their study on 21 Japanese enterprises which are operating in the manufacturing industry traded on the Tokyo Stock Exchange, found a negative correlation between leverage and profitability as a result of panel data and multiple regression analyzes. Similar results were also reported by Chen, Lensink and Sterken (1998); Bevan and Danbolt (2002); Postma et al. (2003); Abor and Biekpe (2005); Haniffa and Hudaib (2006); Hasan and Butt (2009); Hassan (2011); Thippayana (2014); Onofrei et al. (2015); Correia, Cerqueira and Brandão (2015); Singh (2016). At the study of Chechet and Olayiwola (2014), 70 companies traded on the Nigerian Stock Exchange, using data from 2000 to 2009, have found that the borrowing rate negatively affects the profitability of enterprises. Similar results were also determined by Mahmood and Zakaria (2007); Guest (2009); Taghizadeh and Saremi (2013); Mohammadzadeh et al. (2013); Hussain (2015). Zubairi (2010), in his study on 30 companies traded in the automotive sector on Karachi Stock Exchange found that, the financial leverage has a positive effect on profitability of enterprises. Similar results were obtained from the studies of Taub (1975); Ross (1977); Voulgaris, Asteriou and Agiomirgianakis (2004); Frank and Goyal (2009); Wintoki, Linck and Netter (2012); Handoo and Sharma (2014); Katagiri (2014); Ahmad ( 2014) as well.

In financial model; generally, the relationship of financial structure with many factors such as sector, size, growth, taxes, business risk has been investigated. One of the most important issues explored in this area is the relationship between financial structure and profitability. The relationship between financial structure and profitability finds its place particularly in capital structure theories. According to the theory of modern capital structure (M \& M Theory) developed by Modigliani and Miller (1958), which is based on the assumption that there is full competition in capital markets, the type of asset resources that the enterprises financed by has no importance in in terms of business value. Businesses may increase their market values depending on their profit-making powers. Modigliani and Miller made corrections in their study published in 1963 and incorporated the tax shield provided by the debt into their theories. According to their theory, the use of liabilities can increase the profitability and value of the enterprise up to a certain point. According to Kraus and Litzenberger (1973) and Myers (1984), who are one of the proponents of Balancing Theory 
(Trade-offTheory), they stated that the marginal value of the tax shield is related to the increase in the borrowing level. On the other hand, Jensen and Meckling (1976) also underlined that the main determinant of capital structure is the cost of representation including the costs of liability and flotation cost of equity.

Chen and Zhau (2004), in their study of the relationship between the profitability and financial structure of manufacturing enterprises in the USA in the period 1971-2001, stated that profitable enterprises prefer domestic funds to outsources to finance new investments. According to Tong and Green 's (2005) studies on the profitability and financial structure of the largest companies in China indicate that, there is a positive relationship between current leverage ratios and profit shares distributed in the past. Abor (2005) in his study, the effects of financial structures of firms traded on the Ghana Stock Exchange, investigated the profitability of the company; and at the end of his study, he noticed that, there is significant positive relationship between short-term liability and Return on Equity, negative relationship between long-term liability and Return on Equity; and a significant positive relationship between total liability and Return on Equity. In addition, David and Olorunfemi (2010), in the study that examines the effect of financial structure on corporate performance by using panel data analysis method, stated that there is a positive relationship between earnings per share and leverage ratio; Sabir and Malik (2012) reported that profitability is positively correlated with the leverage ratio; Cole et al. (2015) noticed that there is a fundamental negative relationship between financial structure and firm performance, and the financial structure has a negative relationship with return on Assets, operating income and profit margin; Oke and Obalade (2015) stated that profitability is important in determining the financial structures of the companies; Nwaolisa and Chijindu (2016) concluded that the financial structure had a negative impact on the profitability of the firms.

\section{Research}

\subsection{Purpose and Scope of the Research}

The purpose of this study is to determine the effect of financial structure on operational profitability by panel data analysis. In line with this objective, the scope of the study consists of data of 155 companies that can be accessed regularly in a 10-year period between 2008-2017, operating in the BIST ( İstanbul Stock Exchange) Manufacturing sector. The statistical information of the sectors within the scope of the research is as shown in Table 2.

Table 2. Statistical Information on Sectors in the Scope of the Research

\begin{tabular}{|c|l|c|c|c|}
\hline \multicolumn{1}{|c|}{ SECTOR } & $\begin{array}{c}\text { BIST } \\
\text { Number of } \\
\text { Firms }\end{array}$ & $\begin{array}{c}\text { Number of Firms } \\
\text { Included in the } \\
\text { Research }\end{array}$ & $\begin{array}{c}\text { \% Share in } \\
\text { Research }\end{array}$ \\
\hline 1 & Food and Beverage & 31 & 24 & 15 \\
\hline 2 & Textile, Wear and Leather & 21 & 16 & 10 \\
\hline 3 & Forest Products and Furniture & 6 & 3 & 2 \\
\hline 4 & Paper,Paper Products, Printing\& Publishing & 14 & 14 & 13 \\
\hline 5 & Chemicals, Petroleum \& Plastic Products & 31 & 21 & 19 \\
\hline 6 & Stone and Soil Based & 32 & 29 & 12 \\
\hline 7 & Main Metal Industry & 21 & 18 & 19 \\
\hline 8 & Metal Goods, Machinery and Equipment & 32 & 29 & 1 \\
\hline 9 & Other Manufacturing Industry & 5 & 1 & $\mathbf{1 0 0}$ \\
\hline
\end{tabular}

In the scope of the research, statistical data belonging to the sectors is shown in Figure 1. 


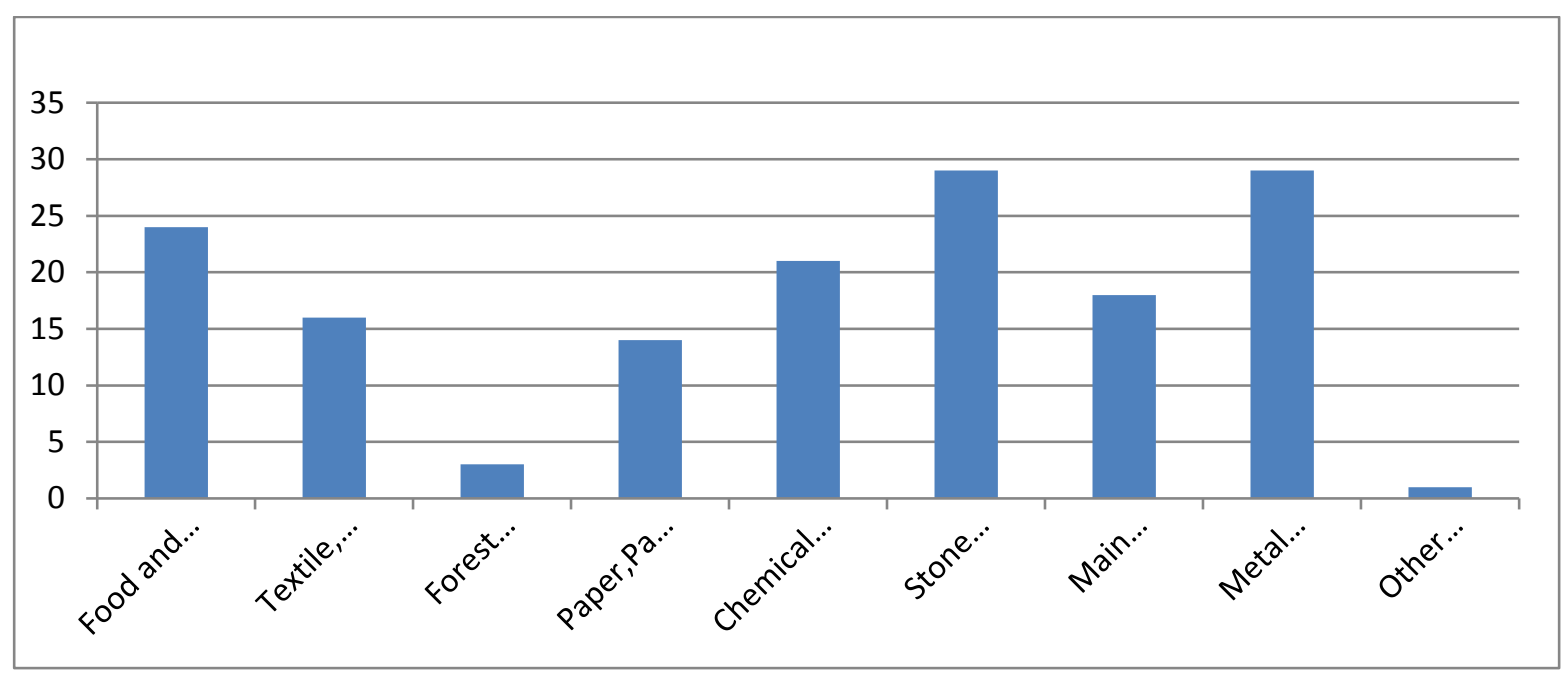

Figure 1. Statistical Information for the Sectors in the Scope of the Research

\subsection{Data Set and Method of Research}

In order to determine the impact of the financial structure on profitability, companies that are operating in the BIST Manufacturing sector were selected. Profitability ratios, which are widely preferred in financial structure ratios and operating performance measurement are used. Financial structure ratios as independent variables, Return on Equity and Asset rates were selected as dependent variable. Financial ratios and related information used as independent variables in the study are taken from the websites of İstanbul Stock Exchange (www.borsaistanbul.com) and Public Disclosure Platform (www.kap.gov.tr).Statistical analysis was performed via the Eviews 9 package program. The financial ratios of dependent and independent variables to be used in the study are shown in Table 3.

Table 3. Financial Ratios and Calculations

\begin{tabular}{|c|c|c|c|}
\hline Variables & Financial Ratios & Symbol & Calculation \\
\hline \multirow{2}{*}{$\begin{array}{l}\text { Dependent } \\
\text { variables }\end{array}$} & Return on Equity Rate & ROE & Net Profit / Equity \\
\hline & Return on Asset Rate & ROA & Net Profit / Total Assets \\
\hline \multirow{12}{*}{$\begin{array}{l}\text { Independent } \\
\text { Variables }\end{array}$} & \multicolumn{3}{|c|}{ Growth Rates } \\
\hline & Asset Growth Rate & AGR & {$\left[\frac{A_{T}-A_{T-1}}{A_{T-1}}\right] * 100$} \\
\hline & Sales Growth Rate & SGR & {$\left[\frac{N S_{T}-N S_{T-1}}{N S_{T-1}}\right] * 100$} \\
\hline & Logarithm of Sales & LOS & \\
\hline & \multicolumn{3}{|c|}{ Financial Structure Rates } \\
\hline & Equity Capital Ratio & $\mathrm{E} / \mathrm{TA}$ & Equity / Total Assets \\
\hline & Total Liability Ratio & TL/E & Total Liability/Equity \\
\hline & Rate of Long-Term Liabilities & LTL/TA & Long-Term Liabilities / Total Assets \\
\hline & Current Liabilities Weight & $\mathrm{CL} / \mathrm{TL}$ & Current Liabilities / Total Liabilities \\
\hline & $\begin{array}{lr}\text { Short-Term } & \text { Financial } \\
\text { Liability Rate } & \\
\end{array}$ & STFL/CL & $\begin{array}{l}\text { Short-Term Financial Liability / } \\
\text { Current Liabilities }\end{array}$ \\
\hline & \multicolumn{3}{|c|}{ Liquidity Ratios } \\
\hline & Current Ratio & CR & $\begin{array}{l}\text { Current Assets / Short Term } \\
\text { Liabilities }\end{array}$ \\
\hline
\end{tabular}

In Table 4,The statistical data of the variables in Manufacturing industry are summarized in the 10-year period between the years 2008-2017. 
H. Özçelik - Z. Arslan 11/1 (2019) 504-516

Table 4. Statistics for Variables

\begin{tabular}{|l|l|c|c|c|c|c|}
\hline \multicolumn{1}{|c|}{ Variables } & $\begin{array}{c}\text { No of } \\
\text { Observations }\end{array}$ & Minimum & Maximum & Average & Median & $\begin{array}{c}\text { Standart } \\
\text { Deviation }\end{array}$ \\
\hline ROE & 1473 & $-8,014$ & 12,356 & 0,038 & 0,066 & 0,484 \\
\hline ROA & 1473 & $-1,193$ & 5,715 & 0,038 & 0,032 & 0,180 \\
\hline AGR & 1473 & $-0,507$ & 4,326 & 0,148 & 0,103 & 0,297 \\
\hline SGR & 1473 & $-0,987$ & 15,932 & 0,143 & 0,102 & 0,512 \\
\hline LOS & 1473 & 5,882 & 10,735 & 8,421 & 8,355 & 0,764 \\
\hline E/TA & 1473 & $-7,674$ & 0,983 & 0,487 & 0,526 & 0,462 \\
\hline TL/E & 1473 & $-65,516$ & 554,556 & 1,053 & 0,843 & 14,889 \\
\hline LTL/TA & 1473 & 0,000 & 2,125 & 0,139 & 0,097 & 0,142 \\
\hline CL/TL & 1473 & 0,011 & 8,619 & 0,374 & 0,332 & 0,409 \\
\hline STFL/CL & 1473 & 0,000 & 0,966 & 0,282 & 0,248 & 0,240 \\
\hline CR & 1473 & 0,070 & 43,860 & 2,153 & 1,540 & 2,307 \\
\hline
\end{tabular}

The impact of the financial structure on profitability will be measured by using the relevant financial ratios. The models to be developed in this context will be tested by panel data analysis. The data set used in this study consists of financial data of 155 firms covering the period of 2008-2017. The data in this data set has the properties of the horizontal and the time series called panel data. The reason for selecting panel data analysis is that time series and horizontal horizontal section data can be used together. The combination of time series and horizontal sectional data provides more flexibility compared to their individual usage since it increases the amount and quality of data (Gujarati, 2004: 638). While the causality analysis between dependent and independent variables is performed, the data sets appear in three different ways. These are time series, horizontal section data and panel data sets. Panel data is defined as horizontal section data with time series or time dimension of multiple sections (Grene, 2003, p. 11). The panel data used in the panel data analysis is superior in many respects to the horizontal sectional data and time series. Panel data; it provides more accurate parameter estimates, since it contains more sample diversity and degree of freedom than the horizontal section data and time series. It allows the creation and testing of complex models and behavioral hypotheses. Because it involves inter-timed relationships and specific information of units, it makes it easier to control unobservable variables (Hsiao, 2007: 2-6). In addition, as the method, panel data (more information than the cross-sectional data and time series data) provides less linear link between the variables, greater degree of freedom and more activity. Panel data can better detect, measure and work with complex behavior patterns in horizontal cross-sectional data or time series data (Baltagi, 2005; Wooldridge, 2002).

Panel data regression is different from a regular time series. A simple regression model in panel data analysis can be estimated as in Equation 1 (Baltagi, 2005: 11, Gujarati, 2004: 640).

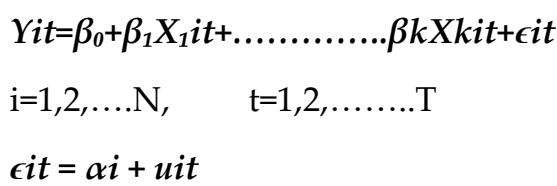

Yit: Dependent variable.

Xit:,K times independent or descriptive variable belong to the model

$\beta$ : Coefficient of explanatory variables

eit: Inclusions

$\alpha \mathrm{i}$ : The degree of heterogeneity

uit: refers compound error term .

On the basis of this model, the models to be tested in the study were constructed as in Equations1 and 2, taking into account the dependent and independent variables used in the study. 
$R O A=\beta_{0^{+}}+\beta_{1} L T L / T A i t+\beta_{2} C L / T L i t+\beta_{3} S T F L / C L i t+\beta_{4} L O S+\beta_{5} S G R+\epsilon i t$

$R O E=\beta_{0}+\beta_{1} E / T A i t+\beta_{2} T L / E i t+\beta_{3} C R i t+\beta_{4} L O S+\beta_{5} A G R+\epsilon i t$

The study is based on the assumption that the financial structure affects the profitability of the enterprise. In line with the hypothesis, the null hypothesis must be tested. The null (zero) and alternative hypotheses to be tested within the scope of the study are designed as follows.

$$
\begin{aligned}
& \text { H0 = Financial structure has no impact on Return On Equity. } \\
& \text { H1 = Financial structure has an ımpact on Return On Asset. } \\
& \text { H0 = Financial structure has no effect on Return On Asset. } \\
& \text { H2 = Financial structure has an impact on Return On Equity. }
\end{aligned}
$$

\subsection{Stability Test Results}

Before going to a statistical analysis of a time series, the stability of the series that will be included in the developed model should be investigated with unit root tests (Ergün and Atay Polat, 2015: 124). In the establishment of econometric models with non-stationary series, Granger and Newbold (1974) stated that the problem of false regression may occur. In order to eliminate the problem of false regression, it is necessary to determine the stability of the series before the model is estimated. For unbalanced panel data, Im, Pesaran and Shin (2003) (IPS) and Phillips-Perron (PP) panel unit root tests with Augmented Dickey-Fuller (ADF) and the second group panel unit root tests are used (Tatoğlu, 2012: 213).

In order to make the data suitable for panel data analysis, the panel unit root test developed by Levin Lin Chu (LLC) in 2002 was used to investigate the root processes of each and common unit within the panel data set. Also to investigate the unit root processes, the Im-Pesaran-Shin (IPS) and the Stability Test for standalone units were applied to the extended Dickey Fuller (ADF) unit test, and the results are shown in Table 5.

Table 5. Unit Root Test Results

\begin{tabular}{|l|r|r|r|r|r|r|}
\hline Method & \multicolumn{2}{|c|}{ LLC } & \multicolumn{2}{c|}{ IPS } & \multicolumn{2}{c|}{ ADF } \\
\hline & Statistics & P Value & Statistics & P Value & Statistics & P Value \\
\hline ROE & $-28,355$ & 0,0000 & $-16,150$ & 0,0000 & $-10,608$ & 0,0000 \\
\hline ROA & $-24,461$ & 0,0000 & $-16,653$ & 0,0000 & $-38,276$ & 0,0000 \\
\hline AGR & $-28,760$ & 0,0000 & $-15,809$ & 0,0000 & $-17,743$ & 0,0000 \\
\hline SGR & $-28,242$ & 0,0000 & $-15,701$ & 0,0000 & $-9,976$ & 0,0000 \\
\hline LOS & $-26,151$ & 0,0000 & $-14,434$ & 0,0000 & $-3,394$ & 0,0114 \\
\hline E/TA & $-28,795$ & 0,0000 & $-15,696$ & 0,0000 & $-8,477$ & 0,0000 \\
\hline TL/E & $-29,149$ & 0,0000 & $-17,696$ & 0,0000 & $-39,515$ & 0,0000 \\
\hline LTL/TA & $-27,908$ & 0,0000 & $-17,940$ & 0,0000 & $-8,133$ & 0,0000 \\
\hline CL/TL & $-25,560$ & 0,0000 & $-19,421$ & 0,0000 & $-6,505$ & 0,0000 \\
\hline STFL/CL & $-4,798$ & 0,0000 & $-14,611$ & 0,0000 & $-13,268$ & 0,0000 \\
\hline CR & $-27,431$ & 0,0000 & $-17,006$ & 0,0000 & $-7,517$ & 0,0000 \\
\hline
\end{tabular}

The hypotheses for the three tests were established as follows.

$\mathrm{H} 0=$ There is a common unit root in the series (Serial is not stabile)

$\mathrm{H} 1=$ There is no general unit root in the series (Serial is stabile)

According to the results of the unit root test, since the probability value for all variables $(P=0,000$ for all values) was less than 0.05, H0 hypothesis was rejected and H1 (hypothesis was accepted and series were stable. According to Levin Lin Chu (LLC) test results, there is no common unit root in all series. According to the results of Im-Pesaran-Shin (IPS); no individual unit root in all series and According to the results of Extended Dickey Fuller (ADF); It was determined that there was no unit root in all the units independent of the units. 


\subsection{Findings and Comments}

The model developed in relation to the effect of financial structure on Return on Asset can be written as in Equation 1.

$R O A=-0,18+0,20 L T L / T A i t-0,06 C L / T L i t-0,06 S T F L / C L i t+0,03 L O S+0,03 S G R+\epsilon i t$ (1)

The following hypotheses related to the Return on Asset have been developed and hypothesis will be tested by panel data analysis.

H0 = Financial structure has no effect on Return on Asset.

H1 = Financial structure has an impact on Return on Asset .

Panel data analysis was used for the hypothesis and model validity of the study. The panel data statistics results for Return on Asset are shown in Table 6.

Table 6. Return on Asset Panel Regression Statistics Results

\begin{tabular}{|c|c|c|c|c|}
\hline \multicolumn{5}{|c|}{ Dependent Variable : ROA } \\
\hline \multicolumn{5}{|c|}{ Method: (Panel Least Squares) } \\
\hline \multicolumn{5}{|l|}{ Period: 2008-2017 } \\
\hline \multicolumn{5}{|c|}{ Horizontal Section (number of Firms) : 136} \\
\hline \multicolumn{5}{|c|}{ Time Series (Number of Period): 10} \\
\hline \multicolumn{5}{|c|}{ Total no of Balanced Observation on the Panel: 1.550} \\
\hline Variable & Coefficient & Standart Error & t-statistics & P Value \\
\hline LTL/TA & 0.1993 & 0.0327 & 6.0811 & ${ }^{*} 0.0000$ \\
\hline $\mathrm{CL} / \mathrm{TL}$ & -0.0638 & 0.0193 & -3.3070 & ${ }^{*} 0.0010$ \\
\hline STFL/CL & -0.0638 & 0.0193 & -3.3070 & ${ }^{*} 0.0010$ \\
\hline LOS & 0.0261 & 0.0060 & 4.3421 & ${ }^{*} 0.0000$ \\
\hline SGR & 0.0294 & 0.0089 & 3.2960 & ${ }^{*} 0.0010$ \\
\hline C & -0.1812 & 0.0511 & -3.5455 & ${ }^{*} 0.0004$ \\
\hline R-Square & 0.0627 & \multicolumn{2}{|c|}{ Dependent Variable Average } & 0.0380 \\
\hline Adjusted R Square & 0.0595 & \begin{tabular}{|l|} 
Dependent \\
Deviation
\end{tabular} & Variable Standard & 0.1809 \\
\hline F- Statistics & 19.647 & Durbin-Watson & Statistics & 2.0525 \\
\hline P Value (F Statistics) & 0.0000 & & & \\
\hline
\end{tabular}

Significant at* $\% 1$ level.

The F-statistical value indicates that the model established in terms of analysis is significant as a whole with $99 \%$ reliability. Besides, when $\mathrm{R}^{2}$ value of the model is examined, it is seen that the value is 0,059 . This $\mathrm{R}^{2}$ value means that the independent variables can explain about $6 \%$ of the changes in the dependent variable. This situation can be interpreted as there may be other variables that determine the profitability of enterprises in general. For the significance of the model, it is necessary to look at the F statistic value. Since the F statistic value is less than 0.05 , our model is significance. When the $\mathrm{P}$ values of the variables in the model are examined, it can be stated that the values of all variables are statistically significant since all of them are less than 0.05. Accordingly, the H0 hypothesis on Return on Asset was rejected and it is noticed that the financial structure had an effect on Return on Asset. According to the results, 1 unit change in LTL/TA ratio resulted in a positive change in Return on Asset of approximately $20 \%$. It was determined that 1 unit change in CL/TL ratio caused a change in the $6 \%$ negative direction on Return on Asset. The financial liability ratio in the short-term liability affected the Return on Asset by 6\%.It was observed that the logarithm of sales and the 1-unit change in sales growth rates had a positive effect of $2 \%$ and $3 \%$ on Return on Asset, respectively.

The model showing the effect of financial structure on Return on Equity may be written as in equation 2 . 
The following hypotheses on Return on Equity have been developed and hypothesis will be tested by panel data analysis.

H0 = Financial structure has no effect on Return on Equity.

H1 = Financial structure has an effect on the Return on Equity.

Panel data analysis was used for the hypothesis and model validity of the study. Panel data statistics results related to Return on Equity are shown in Table 7.

Table 7. Return on Equity Panel Regression Statistics Results

\begin{tabular}{|c|c|c|c|c|}
\hline \multicolumn{5}{|l|}{ Dependent Variable: ROE } \\
\hline \multicolumn{5}{|c|}{ Method: En Küçük Kareler (Panel LeastSquares) } \\
\hline \multicolumn{5}{|c|}{ Period: $2008-2017$} \\
\hline \multicolumn{5}{|c|}{ Horizontal Section (number of Firms): 136} \\
\hline \multicolumn{5}{|c|}{ Time Series (Number of Period): 10} \\
\hline \multicolumn{5}{|c|}{ Total no of Balanced Observation on the Panel: 1.550} \\
\hline Independent Variable & Coefficient & Standart Error & t-statistics & P Value \\
\hline E/TA & 0,0644 & 0,0281 & 2,2915 & ${ }^{* * 0} 0,0221$ \\
\hline TL/E & $-0,0040$ & 0,0008 & $-4,9657$ & ${ }^{*} 0,0000$ \\
\hline CR & 0,0219 & 0,0057 & 3,8169 & ${ }^{*} 0,0001$ \\
\hline LOS & 0,1162 & 0,0162 & 7,1410 & ${ }^{*} 0,0000$ \\
\hline AGR & 0,1442 & 0,0410 & 3,5109 & ${ }^{*} 0,0005$ \\
\hline C & $-1,0335$ & 0,1400 & $-7,3807$ & ${ }^{*} 0,0000$ \\
\hline R-Square & 0,0714 & \multicolumn{2}{|c|}{ Dependent Variable Average } & 0,0380 \\
\hline Adjusted R Square & 0,0682 & \begin{tabular}{|l|} 
Dependent \\
Deviation
\end{tabular} & Jariable $\quad$ Standard & 0,4847 \\
\hline F- Statistics & 22,5801 & Durbin-Watson & tatistics & 2,1093 \\
\hline P Value (F Statistics) & 0,0000 & & & \\
\hline
\end{tabular}

Significant at $\% 1$ level. Significant at** \%5 level

The F-statistical value indicates that the model established in terms of analysis is significant as a whole with $99 \%$ reliability. The independent variables in Table 7 mean that they can account for about $7 \%$ of the change in Return on Equity. Because the F-statistic value of the model is less than 0.01 , our model is significant. When the $P$ values of the variables in the model are examined, it can be stated that the values of all variables are statistically significant since the ratio of E/TA ratio is less than 0,05. Accordingly, the hypothesis $\mathrm{H} 0$ was rejected from the hypothesis on the Return on Equity and it was determined that the financial structure had an effect on the Return on Equity. According to the results; There is a positive relationship between Return on Equity and equity ratio and a negative relationship between Liability ratio. The 1-unit change in the Equity Ratio resulted in a 6\% change in Return on Equity. It is observed that the 1-unit change in the Total Liability / Equity Ratio has an effect of $-0,004$ on the Return on Equity. It is noticed that, Current Rate, Logarithm of sales and 1 unit change in Asset Growth Rates, showed a positive effect on Return on Equity respectively; $2 \%, 12 \%$ and $14 \%$.

\section{Conclusion and Discussion}

The financing policies adopted by the enterprises are one of the important variables that determine their profitability. There are different variables that determine the preference of these policies and the risk and the sector in which these operations are important. When enterprises that are active in the manufacturing sector focus on borrowing in order to increase profitability, their risks increase and this situation may adversely affect profitability due to asset source mismatch. Capital structure or financial structure decisions have been one of the most emphasized issues in the financial literature due to the effects of Cost of capital, capital 
budgeting decisions and firm value. Theoretically, it is expected that the companies that manage the working capital will increase their Return on Asset, and therefore the effect of financial structure rates on Return on Asset become also important.

From this point of view, the hypothesis developed from the effects of financial structure on Return on Asset, the data analysis of the data of the 10-year period between the years 2008-2017 of the manufacturing sector has been tested, and it has been concluded that profitability affects the financial structure of the firm. It is determined that the borrowing rates affect the Return on Asset of financial structure ratios and this effect is positive in the long-term borrowing ratio and negative in the short-term borrowing ratio. The 1-unit change in the long-term borrowing ratio resulted in a positive change of approximately $20 \%$ in the Return on Asset, while the short-term borrowing rate had a negative effect of $6 \%$. On the other hand, it was determined that short-term financial borrowing affected the Return On Assets negatively by $6 \%$. In the 10-year period, it can be said that the long-term borrowing rate of the manufacturing sector remained at a level of $14 \%$ borrowing level, that is below the $17 \%$, which is considered to be reasonable level, about, and positively affected the Return On Assets. It can be stated that the 10-year average value of the short-term borrowing rate is higher than the $33 \%$ of the acceptable value, which is approximately $37 \%$. It is determined that the Equity ratio related to the financial structure positively affects the Return On Equity by about $6 \%$ and the Total Liability / Equity ratio negatively affects -0.004 .

This study can be developed by the subsequent studies by analyzing the impact of financial structure on profitability, by using different econometric methods in different sectors, by revising the analysis period, by examining more firms and by diversifying company specific factors.

\section{References}

Abor, J. (2005). The effect of capital structure on profitability: an empirical analysis of listed firms in ghana, The Journal of Risk Finance, 6(5), 438-445.

Abor, J. and Biekpe, N. (2005). Does corporate governance affect the capital structure decisions of smes? Biennial Conference of the Economic Society of South Africa, Durban, South Africa, September.

Ahmad, T. (2014). Impact of capital structure on profitability: an empirical analysis of cement sector of Pakistan, Research Journal of Finance and Accounting, 5(17),49-54.

Arslan, M. and Boz, M.F. (2017). Analysis of the factors affecting the capital structure of oil exploration and production companies: Comparative analysis of TP and the five major oil exploration and production companies in the World, Işletme Araştırmaları Dergisi, 9(2), 212-231.

Baltagi, B. H. (2005). Econometric Analysis of Panel Data. 3. Edt. England: John Wiley \& Sons Ltd.

Bektöre, S., Çömlekçi, F., ve Sözbilir, H. (2015). Mali Tablolar Analizi, Nisan Kitabevi, Ankara.

Berk, J., DeMarzo, P. and Harford, J. (2012). Fundamentals of Corporate Finance., 2. Bask1. ABD: Pearson Education.

Besley, S. and Brigham, E.F. (2000). Essentials of Managerial Finance, Twelfth Edition, The Drden Press, USA.

Bevan, A. A. and Danbolt, J. (2002). capital structure and its determinants in the united kingdom: a decompositional analysis, Applied Financial Economics, 12(3), 159 - 170.

Chechet, I. L. and Olayiwola, A.B. (2014). Capital structure and profitability of nigerian quoted firms: the agency cost theory perspective, American International Journal Of Social Science, 3(1), 139-158.

Chen, L. H., Lensink R. And Sterken E. (1998). the determinants of capital structure: evidence from dutch panel data, The European Economic Association Annual Congress, Berlin, 1-33.

Chen, L. and Zhau, X. (2004). Profitability, Mean Reversion of Leverage Ratios and Capital Structure Choices, 1-43. 
H. Özçelik - Z. Arslan 11/1 (2019) 504-516

Chen, L. and Zhau, X. (2005). Why Do More Profitable Firms How Lower Leverage Rations?,1-36.

Cole C, Yan Y and Hemley D. (2015). Does capital structure impact firm performance: An empirical study of three U.S. sectors, Journal of Accounting and Finance, 15(6), 57-65.

Correia, A. M. F. A., Cerqueira, A. M. and Brandao, E. (2015). determinants of corporate capital structure: evidence from non-financial listed french firms. FEP Working Papers.

Cortez, M. A. and S. Susanto. (2012). The determinants of corporate capital structure: evidence from japanese manufacturing companies. Journal of International Business Research, 11(3), 121-134.

David D.F. and Olorunfemi S. (2010). capital structure and corporate performance in nigeria petroleum industry: panel data analysis, Journal of Mathematics and Statistics, 6(2), 168-173.

Ergün, S. ve Atay Polat, M. (2015). OECD ülkelerinde CO2 emisyonu, elektrik tüketimi ve büyüme ilişkisi, Erciyes Üniversitesi İIBF Dergisi, 45, 115-141.

Frank, M. Z. and Goyal, V. K. (2009). Profits and capital structure. AFA 2009 San Francisco Meetings Paper.

Granger, C. W. and Newbold, P. (1974). Spurious regressions in econometrics. Journal of Econometrics, 2(2), $111-120$.

Grene, W. H. (2003). Econometric Analysis. Pearson Education India.

Guest, P. M. (2009). The impact of board size on firm performance: evidence from the UK, The European Journal of Finance, 15(4), 385- 404.

Gujarati, D. N. (2004). Basic Econometrics, Fourth Edition. New York, The McGraw-Hill Companies.

Handoo, A., and Sharma, K. (2014). A study on determinants of capital structure in INDİA, IIMB Management Review, 26(3), 170-182.

Haniffa, R. and Hudaib, M. (2006). Corporate governance structure and performance of malaysian listed companies, Journal of Business Finance \& Accounting, 33, 1034- 1062.

Hasan, A. and Butt, S.A. (2009). Impact of ownership structure and corporate governance on capital structure of pakistani listed companies, International Journal of Business and Management, 4(2), 50-57.

Hassan, S.U. (2011). Determinants of capital structure in the nigerian listed insurance firms, International Conference On Management (Icm 2011) Proceeding.

Hsiao, C. (2007). Panel Data Analysis-Advantages and Challenges. TEST, 16(1),1-22.

http://www.borsaistanbul.com (Erişim tarihi: 15 Aralık 2018).

http://www.kap.gov.tr (Erişim tarihi: 15 Aralık 2018).

Hussain, T. (2015). Does capital structure effects profitability of the firms (evidence from firms listed at KSE 100 index), Research Journal of Finance and Accounting, 6(5), 116-123.

Im, K. S., Pesaran, M. H., and Shin, Y. (2003). Testing for unit roots in heterogeneous panels, Journal of econometrics, 115(1), 53-74.

Jensen, M.C. and Meckling, W.H. (1976). Theory of the firm: managerial behavior, agency costs and ownership structure, Journal of Financial Economics, 3(4), 305-360.

Katagiri, M. (2014). A macroeconomic approach to corporate capital structure, Journal Of Monetary Economics, 66, 79-94. 


$$
\text { H. Özçelik - Z. Arslan 11/1 (2019) 504-516 }
$$

Kraus, A. and Litzenberger, R.H. (1973). A state- preference model of optimal financial leverage, Journal of Finance, 28(4), 911-922.

Levin, A., Lin, C.F. and Chu, C. J. (2002). Unit root tests in panel data: asymptotic and finite-sample properties, Journal of Econometrics, 108(1), 1-24.

Mahmood, W.M.W. and Zakaria, R. (2007). Profitability and capital structure of the property and construction sectors in Malaysia, Pacific Rim Property Research Journal, 13(1), 92-105.

Mathur, I. and Singh, M. (2011). Corporate political strategies, Accounting and Finance, 51, 252-277.

McKinsey (2012). Manufacturing the future: the next era of global growth and innovation.

Modigliani, F. and Miller, M.H. (1958). The cost of capital, corporation finance and the theory of investment, The American Economic Review, XLVIII(3), 261-297.

Modigliani, F. and Miller, M.H. (1963). Corporate income taxes and the cost of capital: a correction, The American Economic Review, 53(3), 433-443.

Mohammadzadeh, M., Rahimi, F., Aarabi, S. M. and Salamzadeh, J. (2013). The effect of capital structure on the profitability of pharmaceutical companies, The Case of Iran Iranian Journal of Pharmaceutical Research. 12(3),573-577.

Myers, S.C. (1984) .The capital structure puzzle, The Journal of Finance, 39(3), 574-592.

Nwaolisa, E.F. and Chijindu, A.A. (2016). The influence of financial structure on profitability with special reference to oil and gas firms in nigeria, Advances in Research, 7(1), 1-17.

Oke M.O and Obalade A.A. (2015). Testing the validity of optimal capital structure theory in Nigerian listed oil firms, International Journal of Economics, Commerce and Management, 3(3),1-15.

Okka, O. (2009). Analitik Finansal Yönetim Teori ve Problemler, (1.Baskı), Nobel Yayın Dağıtım, Ankara.

Onofrei, M., Tudose, M. B., Durdureanu, C., and Anton, S. G. (2015). Determinant factors of firm leverage: an empirical analysis at rasi county level. Procedia Economics And Finance, 20, 460-466.

Postma, T. J. B. M., Ees H. V. and Sterken, E. (2003). Board composition and firm performance in the netherlands, Eastern Economic Journal, 29, 41- 58.

Ross, S.A. (1977). The determination of financial structure: the incentive - signaling approach, The Bell Journal of Economics, 8(1), 23-40.

Ross, S. A., Westerfield R. W. and Jaffe, J. (2008). Corporate Finance, 8th Edt. McGraw Hill.

Sabir M. and Malik, Q.A. (2012). Determinants of capital structure: a study of oil and gas sector of Pakistan, Interdisciplinary Journal of Contemporary Research in Business, 3(10), 395-400.

Sarıaslan, H. ve Erol, C. (2014). Finansal yönetim: Kavramlar, kurumlar ve ilkeler,(Gözden Geçirilmiş 2. Bask1), Siyasal Kitabevi, Ankara.

Sheikh, N. A. and Wang, Z. (2011). Determinants capital structure, an emprical study of firms in manifacturing industry of Pakistan, Managerial Finance, 37(2), 117-133.

Singh, D. (2016). A panel data analysis of capital structure determinants: an empirical study of non-financial firms in Oman, International Journal of Economics and Financial Issues, 6(4), 1650-1656.

Taghizadeh, M. and Saremi S. Y. (2013). Board of directors and firms performance: evidence from Malaysian public listed firm. dor: 10.7763/1pedr, 59 (37),178- 182. 


$$
\text { H. Özçelik - Z. Arslan 11/1 (2019) 504-516 }
$$

Tatoğlu, F.Y. (2012). Panel Veri Ekonometrisi: Stata Uygulamalı, Beta Yayınları, İstanbul.

Taub, A.J. (1975). Determinants of the firm's capital structure, Review of Economics and Statistics, 57, 410-416.

Thippayana, P. (2014). Determinants of capital structure in Thailand, Procedia-Social And Behavioral Sciences, $143,1074-1077$.

Tong, G. and Green, C. J. (2005). Pecking order or trade-off hypothesis? evidence on the capital structure of Chinese companies, Applied Economics, 37(19), 2179-2181.

Topaloğlu, E.E. (2018). Sermaye yapısına etki eden firmaya özgü faktörlerin panel veri analizleri ile belirlenmesi: kurumsal yönetim endeksi üzerine bir uygulama, Finans Politik \& Ekonomik Yorumlar (640) Haziran, 63-100.

Voulgaris, F., Asteriou, D. and Agiomirgianakis, G. (2004). Size and determinants of capital structure in the greek manufacturing sector, International Review of Applied Economics, 18(2), 247-262.

Wintoki, M. B., Linck, J. S. and Netter, J. M. (2012). Endogeneity and the dynamics of internal corporate governance, Journal of Financial Economics, 105, 581-606.

Wooldridge, J. M. (2002). Econometric Analysis of Cross Section and Panel Data, The MIT Press. Cambridge Massachusetts, London.

Zubairi, H. J. (2010). Impact of working capital management and capital structure on profitability of automobile firms in pakistan, Finance and Corporate Governance Conference Paper,1-18. 